\title{
A Bibliometric Analysis and Visualisation of Research Trends in Allergy of Cobalt Implants
}

\author{
Ranvijay Singha \\ Department of Mechanical Engineering, Chandigarh University, Gharuan, Punjab,India. 140413
}

Article History: Received: 11 January 2021; Accepted: 27 February 2021; Published online: 5 April 2021

\begin{abstract}
The metal hypersensitivity of implants is a vital factor affecting the safety of implants. The bibliometric analysis had been conducted to understand the active authors, organizations, journals, and countries involved in the research domain of "allergy of Cobalt implants". All published articles related to "allergy of Cobalt implants" from "Scopus", were analyzed using the VOS viewer to develop analysis tables and visualization maps. This article had set the objective to consolidate the scientific literature regarding "allergy of Cobalt implants" and also to find out the trends related to the same. The most active journal in this research domain was Contact Dermatitis. The most active countries were the United States of America and Germany. The leading organization of this research domain was Ludwig Maximilian University of Munich, Germany. The most active author who had made valuable contributions related to the allergy of Cobalt implants was Thomas P.
\end{abstract}

Keywords: Allergy of implants, Cobalt implant, Material engineering, Bibliometric analysis, VOS viewer,

\section{Introduction}

Allergy of metals is a serious issue associated with metal implants. The allergy may be of varying degrees to different patients [1]. Metal hypersensitivity at an extreme stage may even lead to failure of implant or replacement of implant with a comparatively safe metal. Different types of metals [2]-[4]and materials are used to create implants and the most popularly used metals and alloys for bio-implants are stainless steel, cobaltchromium alloy, and Titanium[5]. Various types of implants had been used in modern medicine and include sensory implants, neurological implants, cardiovascular implants, orthopedic implants, contraceptive implants, and cosmetic implants.

Despite having various advantages associated with implants, the safety of implants is an important parameter associated with acceptance. The allergy or hypersensitivity of implants and treatments to reduce implants is an important matter to be addressed. Material engineering and surface engineering play a vital role in the selection and usage of safe metals and alloys as implants. The hypersensitivity of the implant can be worse due to wear and corrosion of the metal; and through allergy of the metal implant. Serious health issues due to corrosion and wear of metal-metal implants based on Cobalt and Chromium [6][7] Implants derived Cobalt-Chromium and molybdenum (CoCrMo alloy) nanoparticle disrupts DNA replication dynamics in neuronal cells [8] Toxicity and allergy due to implants based on cobalt-chromium alloys [9];[10].

This bibliometric analysis will be a useful platform for future researchers by realizing the top researchers, organizations, and countries involved in research regarding the hypersensitivity of Cobalt based-implants. This article is arranged into four sections. The first section is the introduction, followed by the discussion of the methodology by which the research was conducted. The third section deals with results and discussion. The fourth section deals with the conclusion. The following research objectives and research questions were framed for conducting bibliometric analysis systematically.

\subsection{Research Objectives}

a) To consolidate the literature regarding the allergy of cobalt implants

b) To find out the trends related to research in allergy of cobalt implants

\subsection{Research Questions}

a) Who are the active researchers working on the allergy of cobalt implants?

b) Which are the main organizations and countries working on the allergy of cobalt implants?

c) Which are the main journals related to the allergy of cobalt implants?

\section{Research Methodology}

Scopus files had been used for this article. For the article selection, the Boolean used was TITLE-ABS-KEY (Allergy Cobalt Implants) on 03/03/2021. All the tables in this paper were created by using Microsoft Excel and VOS Viewer. Grammarly was used for spelling and grammar checks. Mendeley was used for article review and citation. This paper had been inspired by bibliometric analysis in its presentation style, analysis, and methodology from the works [11]-[17]. 


\section{Results and discussion}

\subsection{Results}

This first round of search produced an outcome of 196 documents, in five languages, out of which 151 documents were in English. The classification of document categories is shown in Figure 1. For improving the quality of the analysis, we had selected only the peer-reviewed articles and all other documents had not been considered. Thus after using filters "Article" and "English" the second round search produced an outcome of 101 English articles (both open access and others) and had been used to conduct bibliometric analysis and visualization using VOS Viewer. The English research articles in this domain since 1976 had been shown in Figure 2.

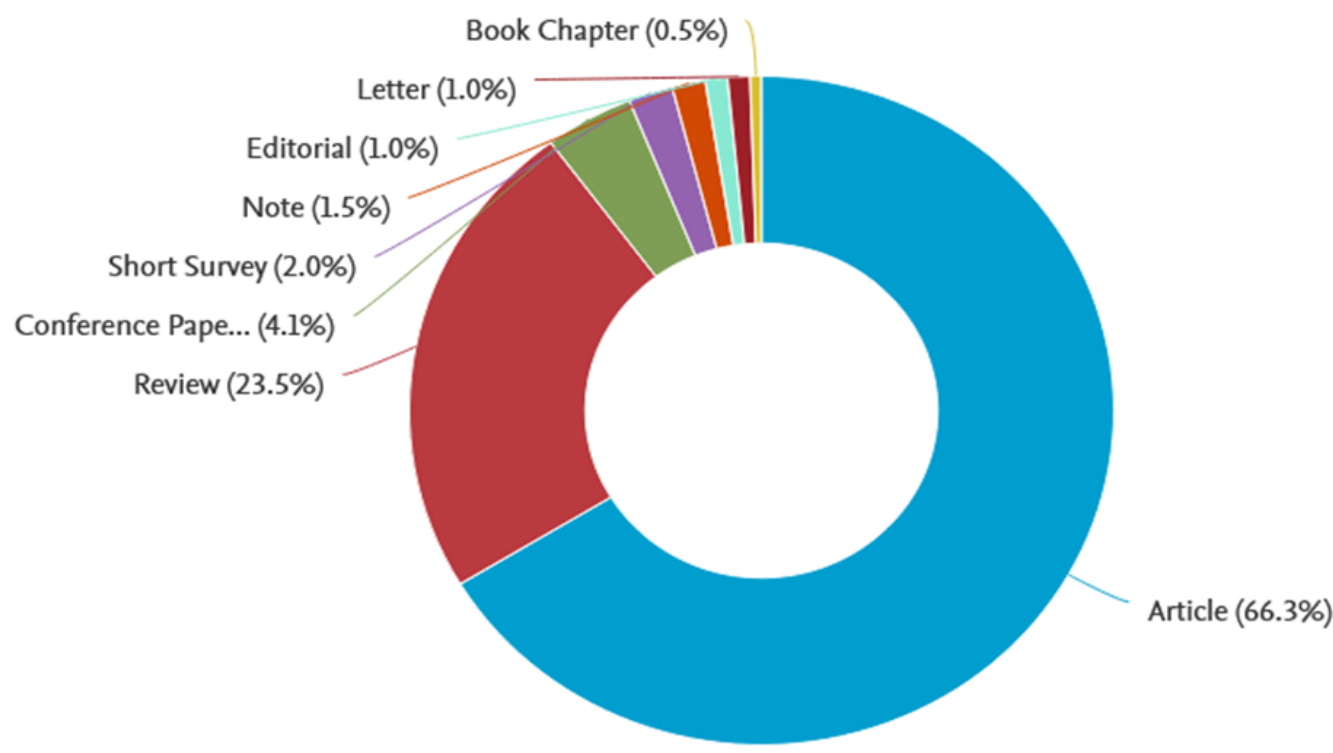

Figure 1: Classification of the documents on "Toxicity of Chromium implants", Source: www.scopus.com 12

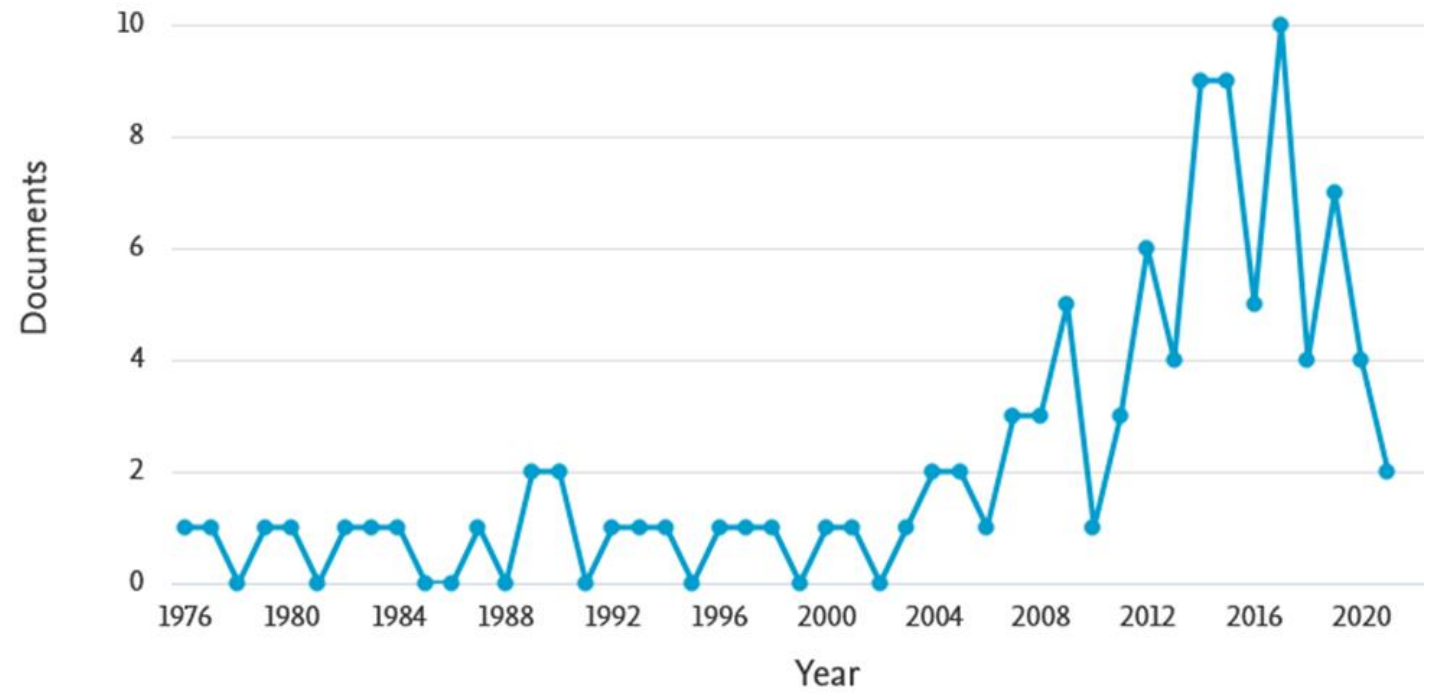

Figure 2: Period wise publication of articles, Source: WWW.scopus.com

Co-authorship analysis of top authors had been shown in figure 3. For a better presentation of the analysis, the parameters used were the minimum number of documents of an author as two and the minimum number of citations of authors as one. This combination plotted the map of 35 authors, in 15 clusters. The overlay visualization map of co-authorship analysis plotted in Figure 3, points out the major researchers with their strong co-authorship linkages and clusters involved. 


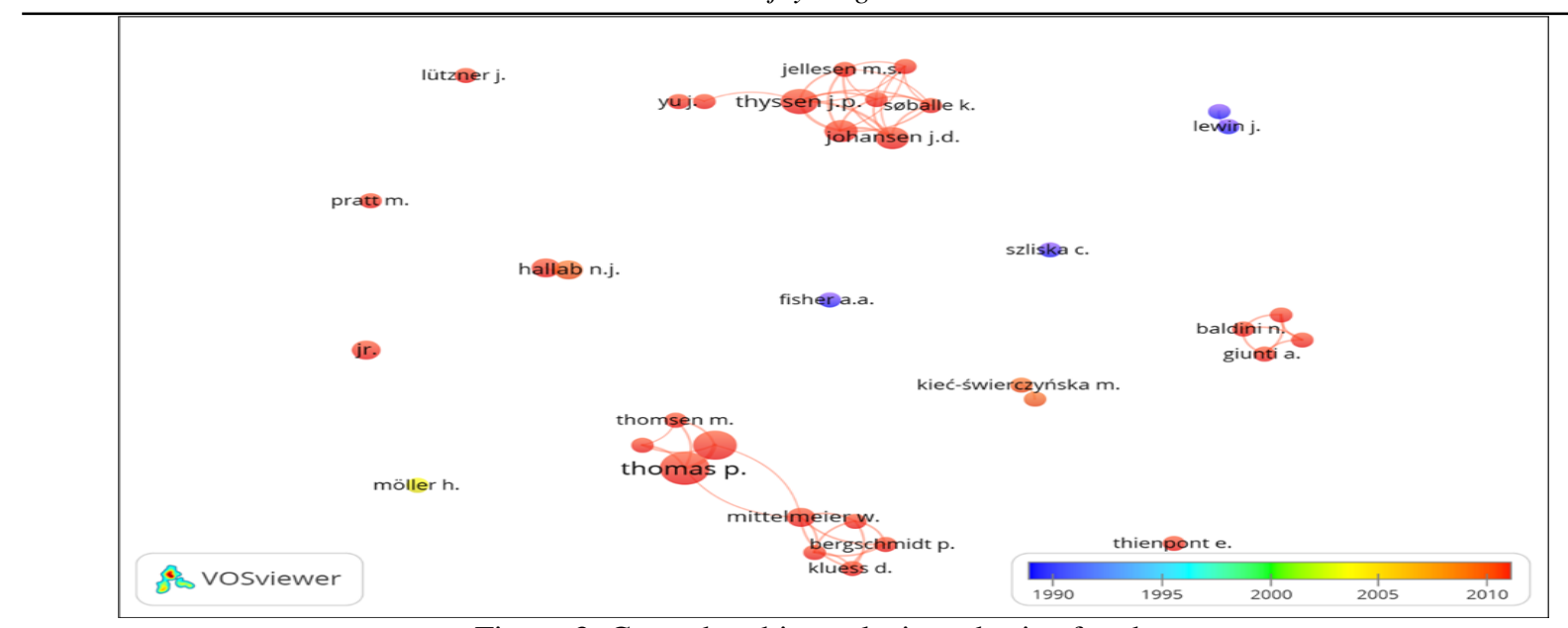

Figure 3: Co-authorship analysis on basis of authors

The citation analysis of top authors had been shown in table 1, along with co-authorship links. For the citation analysis, the parameters used were the minimum number of documents of an author as one and the minimum citations of an author as one.

Table 1: Highlights of most active authors

\begin{tabular}{|c|r|r|r|r|r|}
\hline Description & Authors & Documents & Citations & $\begin{array}{c}\text { Average } \\
\text { citations } \\
\text { per } \\
\text { documents }\end{array}$ & $\begin{array}{r}\text { Link } \\
\text { strength }\end{array}$ \\
\hline $\begin{array}{c}\text { Authors with the } \\
\text { highest publication, } \\
\text { citations, and co- } \\
\text { authorship links }\end{array}$ & Thomas. & 9 & 361 & & \\
\hline
\end{tabular}

In Co-occurrence analysis, we had used all keyword analyses, by keeping the minimum number of occurrences of a keyword as 15 . This combination plotted the map of 37 thresholds, in three clusters. The overlay visualization of co-occurrence analysis of keywords has been shown in Figure 4.

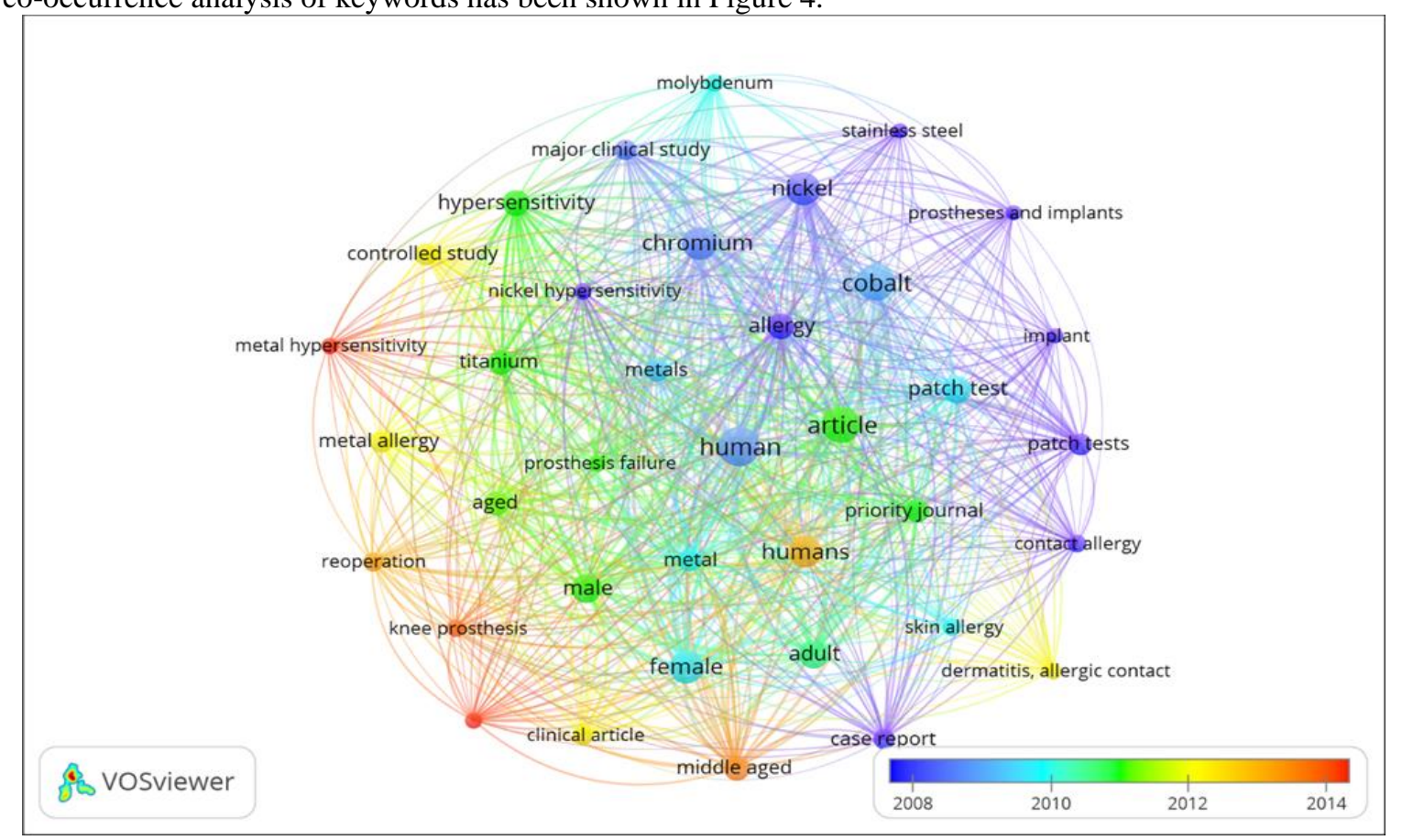

Figure 4: Co-occurrence analysis on basis of all keywords

The leading organizations engaged in research on the "allergy of Cobalt implants" had been found out by the volume of publications and citation analysis, the parameters used are the minimum number of documents of an organization as one and the minimum number of citations of organizations as one. The leading organizations in the research regarding "allergy of Cobalt implants", with the highest number of publications and citations, were the Ludwig Maximilian University of Munich, Germany. (Refer to table 2).

Table 2: Highlights of the most active organization 


\begin{tabular}{|c|c|c|c|c|}
\hline Organizations & Country & s Document & $\begin{array}{c}\text { Citatio } \\
\text { ns }\end{array}$ & $\begin{array}{c}\text { Average } \\
\text { Citations } \\
\text { per } \\
\text { document }\end{array}$ \\
\hline $\begin{array}{c}\text { Ludwig Maximilian University } \\
\text { of Munich }\end{array}$ & Germany & 9 & 361 & 40 \\
\hline
\end{tabular}

Co-authorship analysis of the countries engaged in the research on "Allergy Cobalt of implants" had been shown in Figure 5. The overlay visualization map of co-authorship analysis plotted in Figure 5, points out the main countries with their strong co-authorship linkages and clusters involved.

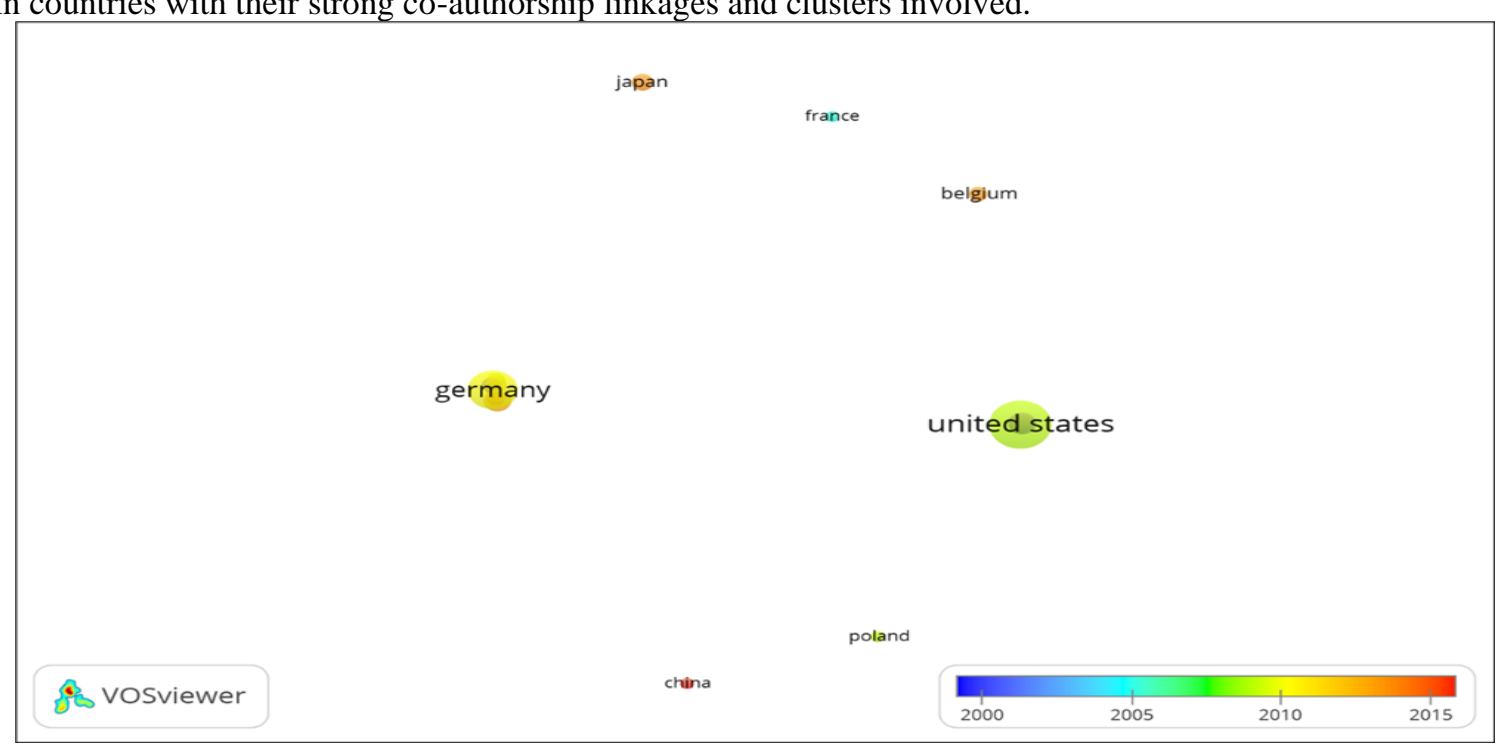

Figure 5: Co-authorship analysis on basis of countries

The citation analysis of top countries had been shown in table 3, along with co-authorship links. For the citation analysis, the parameters used were the minimum number of documents of a country as one and the minimum citations of the country as one.

Table 3: Highlights of Active Countries

\begin{tabular}{|c|c|c|c|c|}
\hline Description & Country & Document & Citation & Link strength \\
\hline $\begin{array}{c}\text { The country with the } \\
\text { highest publication and } \\
\text { citations }\end{array}$ & $\begin{array}{c}\text { United States of } \\
\text { America }\end{array}$ & 33 & 828 & 2 \\
\hline $\begin{array}{c}\text { The country with the } \\
\text { highest co-authorship links }\end{array}$ & Germany & 22 & 498 & 5 \\
\hline
\end{tabular}

The most active country in this research domain was the United States of America and Germany, with the highest number of publications and citations; and co-authorship links respectively.

Link analysis and citation analysis were used to identify the most active journal in this research domain. We have taken the parameters of the minimum number of documents of a journal as one and the minimum number of citations of a journal as one for the link analysis and citation analysis. Highlights of the most active and relevant journals related to "toxicity of chromium implants" are shown in table 4 . Table 4 shows the journal activity of this research domain through parameters of publication volume, citations, and co-authorship linkages.

Table 4: Analysis of journal activity

\begin{tabular}{|c|r|r|r|r|}
\hline Description Journal details & Documents & Citations & $\begin{array}{c}\text { Average } \\
\text { citations per } \\
\text { documents }\end{array}$ \\
\hline $\begin{array}{l}\text { Journal with the } \\
\text { highest publications, } \\
\text { citations, and co- } \\
\text { authorship links }\end{array}$ & Contact Dermatitis & & & \\
\hline
\end{tabular}

From the above discussion regarding the bibliometric patterns in the research regarding "allergy of Cobalt implants", this research had observed a gradual increase in research interest regarding "allergy of Cobalt implants" from the starting of the millennium and the momentum is going on positively. This points out the relevance and potential of this research domain (Refer to Figure 2). The most active author in this research domain was Thomas P. with the highest publication, citations, and co-authorship (Refer to table 1). The overlay analysis of top countries researching "allergy of Cobalt implants" indicates that the United States of America and Germany 
were the leading country relating to the highest number of publications, citations, and co-authorship links (Refer to figure 5). The top journal of this research domain was identified as the Contact Dermatitis with the highest publication, citations, and co-authorship links. From these wide sources of information, researchers can focus on top journals where they can identify the most relevant and highly cited articles regarding the allergy of Cobalt implants.

\section{Conclusion}

Allergy of Cobalt implants was an interesting research domain and the most active journal related to this research domain was Contact Dermatitis. The most active countries were the United States of America and Germany. The leading organization was Ludwig Maximilian University of Munich, Germany. The most active author who had made valuable contributions related to the allergy of Cobalt implants was Thomas P. with the highest publication, citations, and co-authorship links. This research domain offers a new avenue for researchers and future research can be on innovations in the allergy of Cobalt implants.

\section{References}

1. Kolkailah et al., "Bibliometric Analysis of the Top 100 Most Cited Articles in the First 50 Years of Heart Transplantation," Am. J. Cardiol., vol. 123, no. 1, pp. 175-186, 2019.

2. G. Cobb and T. P. Schmalzreid, "The clinical significance of metal ion release from cobalt-chromium metal-on-metal hip joint arthroplasty,” Proc. Inst. Mech. Eng. Part H J. Eng. Med., vol. 220, no. 2, pp. 385-398, 2006.

3. T. Abbas et al., "Sustainability assessment associated with surface roughness and power consumption characteristics in nanofluid MQL-assisted turning of AISI 1045 steel," Int. J. Adv. Manuf. Technol., vol. 105, no. 1-4, pp. 1311-1327, Nov. 2019.

4. X. Tran et al., "The current research landscape of the application of artificial intelligence in managing cerebrovascular and heart diseases: A bibliometric and content analysis,” Int. J. Environ. Res. Public Health, vol. 16, no. 15, 2019.

5. Bijukumar, A. Segu, I. I. Chastain P., and M. T. Mathew, "Implant-derived CoCrMo alloy nanoparticle disrupts DNA replication dynamics in neuronal cells," Cell Biol. Toxicol., 2021.

6. Singh, V. Kumar, and M. Kaur, "Single image dehazing using gradient channel prior,” Appl. Intell., vol. 49, no. 12, pp. 4276-4293, Dec. 2019.

7. Shahid et al., "Characteristics of highly cited articles in heart failure: A bibliometric analysis," Future Cardiol., vol. 16, no. 3, pp. 189-197, 2020.

8. J. Liao et al., "The most cited articles in coronary heart disease: A bibliometric analysis between 1970 and 2015," Int. J. Cardiol., vol. 222, pp. 1049-1052, 2016.

9. J. R. Campbell and M. P. Estey, "Metal release from hip prostheses: Cobalt and chromium toxicity and the role of the clinical laboratory," Clin. Chem. Lab. Med., vol. 51, no. 1, pp. 213-220, 2013.

10. L. Rodríguez-Padial et al., "Trends and Bibliometric Impact of Research Grants of the Spanish Society of Cardiology/Spanish Heart Foundation (2007-2012) [Evolución e impacto bibliométrico de las becas de la Sociedad Española de Cardiología/Fundación Española del Corazón en el periodo,” Rev. Esp. Cardiol., vol. 72, no. 12, pp. 1012-1019, 2019.

11. N. Aggarwal, K. Kaur, A. Vasishth, and N. K. Verma, "Structural, optical and magnetic properties of Gadolinium-doped ZnO nanoparticles,” J. Mater. Sci. Mater. Electron., vol. 27, no. 12, pp. 13006-13011, 2016.

12. O. M. Posada, R. J. Tate, and M. H. Grant, "Toxicity of cobalt-chromium nanoparticles released from a resurfacing hip implant and cobalt ions on primary human lymphocytes in vitro," J. Appl. Toxicol., vol. 35, no. 6, pp. 614-622, 2015.

13. O. M. Posada, R. J. Tate, R. M. Dominic Meek, and M. Helen Grant, "In Vitro analyses of the toxicity, immunological, and gene expression effects of cobalt-chromium alloy wear debris and co ions derived from metal-on-metal hip implants," Lubricants, vol. 3, no. 3, pp. 539-568, 2015.

14. P. Priyanka et al., Role of nanogrooves on the performance of ultra-fine grained titanium as a bio-implant. Apple Academic Press, 2014.

15. S. Akil, J. M. Newman, N. V Shah, N. Ahmed, A. J. Deshmukh, and A. V Maheshwari, "Metal hypersensitivity in total hip and knee arthroplasty: Current concepts," J. Clin. Orthop. Trauma, vol. 9, no. 1, pp. 3-6, 2018.

16. S. Ullah, S. U. Jan, H. U. Rehman, N. I. Butt, M. A. Rauf, and S. Shah, "Publication trends of Pakistan Heart Journal: A bibliometric study,” Libr. Philos. Pract., vol. 2019, 2019.

17. T. Farhat et al., "Research in congenital heart disease: A comparative bibliometric analysis between developing and developed countries," Pediatr. Cardiol., vol. 34, no. 2, pp. 375-382, 2013. 